Article

\title{
Simple Yeast-Direct Catalytic Fuel Cell Bio-Device: Analytical Results and Energetic Properties
}

\author{
Mauro Tomassetti ${ }^{1,2}, *(\mathbb{D})$, Emanuele Dell' Aglio $^{1}\left(\mathbb{D}\right.$, Mauro Castrucci ${ }^{1}$, Maria Pia Sammartino ${ }^{1}(\mathbb{D}$, \\ Luigi Campanella ${ }^{1}$ (D) and Corrado Di Natale ${ }^{2}$ (i) \\ 1 Department of Chemistry, First University of Rome "La Sapienza", P.le A. Moro 5, 00185 Rome, Italy; \\ emanuele.dell.aglio@gmail.com (E.D.); mauro.castrucci@libero.it (M.C.); \\ mariapia.sammartino@uniroma1.it (M.P.S.); luigi.campanella@uniroma1.it (L.C.) \\ 2 Department of Electronic Engineering, University of Rome "Tor Vergata", Via Politecnico 1, 00133 Rome, Italy; \\ dinatale@uniroma2.it \\ * Correspondence: mauro.tomassetti@uniroma1.it
}

check for updates

Citation: Tomassetti, M.; Dell'Aglio, E.; Castrucci, M.; Sammartino, M.P.; Campanella, L.; Di Natale, C. Simple Yeast-Direct Catalytic Fuel Cell Bio-Device: Analytical Results and Energetic Properties. Biosensors 2021, 11, 45. https://doi.org/10.3390/ bios11020045

Received: 16 December 2020

Accepted: 9 February 2021

Published: 11 February 2021

Publisher's Note: MDPI stays neutral with regard to jurisdictional claims in published maps and institutional affiliations.

Copyright: (c) 2021 by the authors. Licensee MDPI, Basel, Switzerland. This article is an open access article distributed under the terms and conditions of the Creative Commons Attribution (CC BY) license (https:// creativecommons.org/licenses/by/ $4.0 /)$.

\begin{abstract}
This paper reports the analytical detection and energetic properties of a glucose-fed Direct Catalytic Fuel Cell (DCFC) operated in association with yeast cells (Saccharomyces Cerevisiae). The cell was tested in a potentiostatic mode, and the operating conditions were optimized to maximize the current produced by a given concentration of glucose. Results indicate that the DCFC is characterized by a glucose detection limit of the order to $21 \mathrm{mmol} \mathrm{L}^{-1}$. The cell was used to estimate the "pool" of carbohydrate content in commercial soft drinks. Furthermore, the use of different carbohydrates, such as fructose and sucrose, has been shown to result in a good current yield.
\end{abstract}

Keywords: direct catalytic fuel cell; coupled yeast cells; glucose sensing; power source

\section{Introduction}

Fuel cells are promising devices for small-scale power generation (fuel cells as energy generator). As the produced energy depends on the amount of fuel, they also find application as chemical sensors (fuel cells as sensors).

A noticeable number of studies have been reported in the literature concerning fuel cells of different types and configurations which evaluate the conversion of chemical energy into electrical energy, using hydrogen or more complex compounds as fuel, such as methanol, ethanol, or glucose [1-3]. Fuel cells have also been used in the past by present authors to quantify alcohol content in foods, drinks, and pharmaceutical preparations [4-6], while in this paper authors investigated the analytical survey of the Direct Catalytic Fuel Cell (DCFC) fuel cell for glucose determination, not neglecting to evaluate the energy production from glucose solution.

Several types of glucose-based fuel cells have been reported in the literature, such as direct abiotic fuel cells which use gold-platinum as a catalyst [7-9]; these devices were also proposed as implantable abiotic glucose fuel cells $[10,11]$. Among fuel cells, those based on biological processes are particularly appealing for their inherent sustainability. Enzymatic glucose biofuel cells were fabricated [12-14], using enzymes such as glucose oxidase and laccase as electrocatalysts, however they have limited stability [8]. Lastly microbial fuel cells have been studied, where the different systems of a whole electroactive microorganism were used [15-17]. Among fuel cells, those based on biological processes are particularly appealing for their inherent sustainability. In these devices, microorganisms are used as the primary engine of biological processes for energy production. In the present paper we emphasized the use of a simple commercial DCFC device, coupled with Saccharomyces Cerevisiae cells, for analytical purpose, i.e., for glucose determination. As reported in the reference [17] of the present paper, other researchers also addressed the same topic, especially to investigate energy production. However, as can easily be seen, 
reading the paper cited in reference [17], practically all these researchers have worked on rather complex systems, typically involving the immobilization of yeast in the anodic compartment of the fuel cell along with an exogenous mediator, like methylene blue, or bromocresol, or eriochrome, and so on. Initially, we also experimented with devices based on similar configurations but, due to the lackluster results obtained, the difficulties of their realization, and above all the short duration of these devices, we immediately opted for a simpler, more practical, and above all more durable device. We have, in fact, noticed that the immobilization of yeast in the anodic sector of the cell necessarily requires the use of a very limited quantity of yeast (and this does not represent an advantage, given the very low cost of commercial yeasts, such as Saccaromyces Cerevisiae), which involves a very low reproducibility of the measures and limits, almost entirely, the use of the device for analytical purposes. This is due to the fact that any immobilized yeast cell—statistically removed from the support- - tends to clog the separation membrane, rapidly decreasing the ionic permeability and thus also limiting the life of the device from an energy point of view. On the contrary, the device described in our work involves the use of yeast placed in an external thermostated vessel, in addition to an efficient filtering system that does not allow the penetration of any yeast cells (or other particles) in the anodic compartment of the fuel cell. This makes measures much more repeatable, especially for analytical purposes, and increases the use of the same fuel cell, practically for an unlimited time. In addition, the latter can also be a simple inexpensive fuel cell available on the market (as in our case). It is clear that even in our device it is possible to immobilize the yeast, but in this case, this occurs in the external vessel. We performed tests using immobilized yeast placed in a special thermostated column, but soon gave up the immobilization. We preferred to use it free in solution under slight stirring because, using a commercial yeast, its cost was practically negligible. Furthermore, it was possible to thermostat the system as well as the possibility of easily optimizing the various operating parameters, which brought great advantages to the efficiency and repeatability of the measurement-very useful especially in analytical applications.

In the present research, we also investigated the interplay between the energy production and the glucose quantification in a Yeast Direct Catalytic Fuel Cell (YDCFC). In practice, the fuel cell exploited the fermentation reaction induced by yeast cells (Saccaromyces Cerevisiae in our case) by converting glucose into ethanol through the following reaction:

Glucose $(1 \mathrm{~mol}) \stackrel{(\text { Yeast })}{\rightarrow}$ Pyruvate $(2 \mathrm{~mol}) \rightarrow$ Acetaldehyde $(2 \mathrm{~mol}) \rightarrow$ Ethanol $(2 \mathrm{~mol})$ The produced ethanol was then used as the actual fuel for the DCFC device resulting in electric energy. This paper shows that the system can be used both for glucose detection and to estimate the energy production.

\section{Materials and Methods}

The solutions used for all the experiments were made by dissolving in $30 \mathrm{~mL}$ of distilled water; $0.34 \mathrm{~g}$ of Glycine (Fluka, Seelze, Germany, assay > 99\%). Glycine solution $(30 \mathrm{~mL})$ was used to make an isotonic solution $\left(0.15 \mathrm{~mol} \mathrm{~L}^{-1}, \mathrm{pH}=6.0\right)$ with $0.6 \mathrm{~g}$ of yeast (Saccharomyces Cerevisiae). Glucose D (+)-Glucose Monohydrate was purchased from Fluka (Seelze, Germany, assay $>99 \%$ ), while commercial yeast preparation was purchased from a local shop.

A Mettler PM460 balance (Columbus, OH, USA) was used for weighing all solid products. Figure 1 shows the experimental apparatus used for batch measurements.

A $50 \mathrm{~mL}$ glass flask, properly closed with a glass stopper and filled with $30 \mathrm{~mL}$ of yeast-glucose-glycine solution, was kept at a constant temperature of either $25 \pm 0.5^{\circ} \mathrm{C}$, for $24 \mathrm{~h}$, or $28.5 \pm 0.5^{\circ} \mathrm{C}$, for $12 \mathrm{~h}$. The yeast was kept in suspension by a magnetic stirrer, set at $100 \mathrm{rpm}$. 


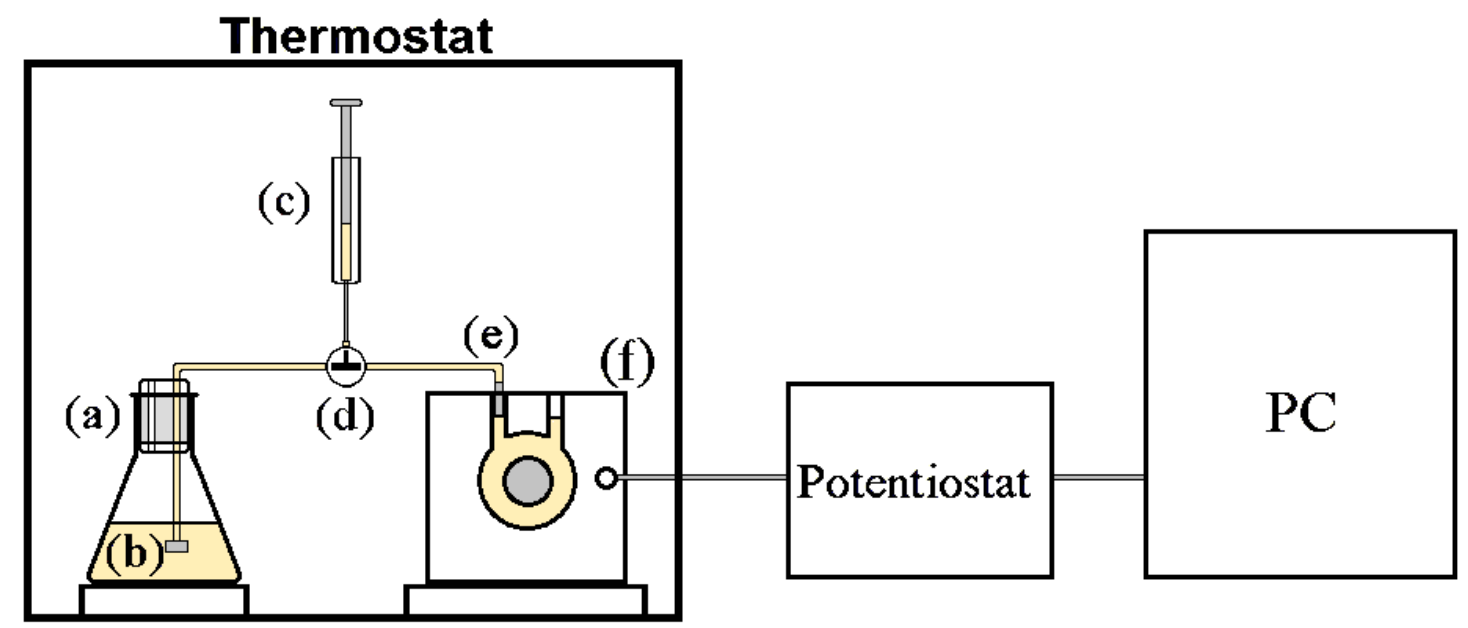

Figure 1. Experimental apparatus: (a) flask containing glucose and yeast in glycine solution; (b) first small filter; (c) graduated syringe; (d) turning tap; (e) second small filter; (f) catalytic fuel cell.

At the end of the incubation time, $2 \mathrm{~mL}$ of solution was quickly extracted from the flask with a device made by graduated syringe, equipped with two small filters (see Figure 1), and injected in the DCFC. The cell was a HTEC Model F111 fuel cell $(50 \times 50 \times 40 \mathrm{~mm}$ and weighing $100 \mathrm{~g}$ ), produced by Fuel Cell Store (College Station, TX, USA).

The Cell walls were in Plexiglas ${ }^{\odot}$ and the end plate of the electrode was made of a Pt-Ru black catalyst, assembled with a Nafion ${ }^{\mathrm{TM}}$ membrane.

The cell was used in a potentiostatic mode by measuring the so-called supplied current $[4,5,18]$. For this purpose, an EmStat potentiostat from Palmsens, connected to a PC, was used. The PSTrace Software (release 4.6) to acquire data and to set the potentiostat, was used. The fuel cell Pt-Ru anode was connected to the potentiostat as a working electrode, while the Pt cathode was connected to both the reference and the counter electrodes. The open circuit voltage (OCV) was measured for approximately $200 \mathrm{~s}$ before any measurement, after that the anode potential was set to OCV-100 $\mathrm{mV}[4,5]$. The supplied current was recorded after $60 \mathrm{~min}$ from the injection of the solution in the fuel cell. Before any measurement, the fuel cell was rinsed, firstly with $0.5 \%$ ethanol-water solution, then by distilled water.

\section{Results}

First, the glucose sensing properties of the fuel cell were investigated. Using the apparatus illustrated in Figure 1, adding glucose alone to the solution in the flask, then injecting this solution into the fuel cell without any previous yeast treatment, no readable current signal was observed. Therefore, the electromotive force and the resulting current appear only after the addition of yeast cells (Saccharomyces Cerevisiae) to the glucose solution contained in the flask.

Lastly the operating conditions were optimized by running the DCFC with the yeast cells in isotonic glycine solution at room temperature. Accordingly, the fuel cell current, at fixed and maintained constant glucose concentration, was measured as a function of the increasing quantity of yeast added (Figure 2), or of the increasing contact time (Figure 3a), by operating at $25^{\circ} \mathrm{C}$, for the best production of ethanol and to maximize the electromotive force. As can be seen in the curves reported respectively in Figures 2 and 3a, it was found that $0.6 \mathrm{~g}$ of yeast in $30 \mathrm{~mL}$ glucose solution and $24 \mathrm{~h}$ of contact time, resulted in best conditions. Using these best conditions, the fuel cell response, with respect to the increase in glucose concentration in the aqueous glycine solution contained in the flask, was measured in order to obtain the calibration curve reported in Figure 4a. This calibration curve was obtained by measurements performed using the fuel cell operating in optimal conditions, at constant temperature of $25^{\circ} \mathrm{C}$ and with the procedure described in the chapter "Material and Methods". 


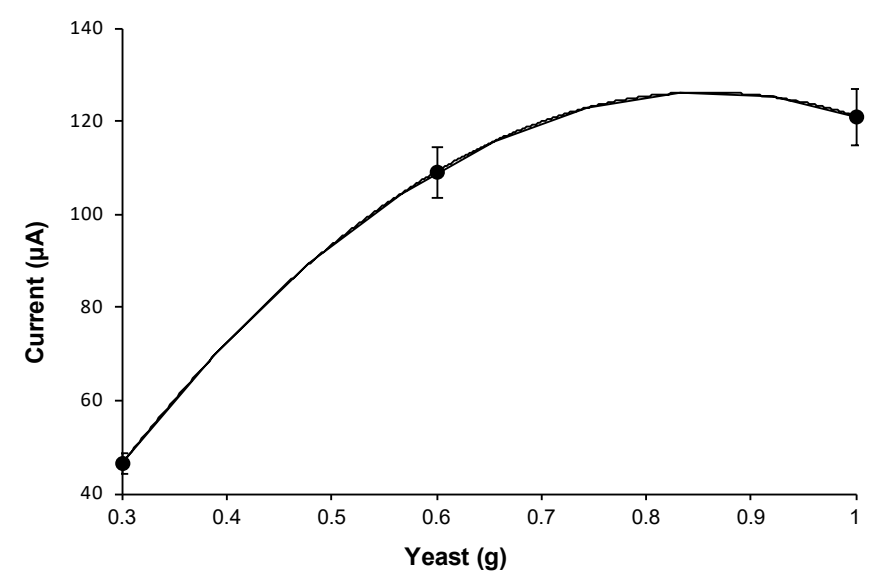

Figure 2. Current intensity recorded as the amount of yeast (g) in solution increases, for a fixed glucose concentration of $0.056 \mathrm{~mol} \mathrm{~L}^{-1}$.
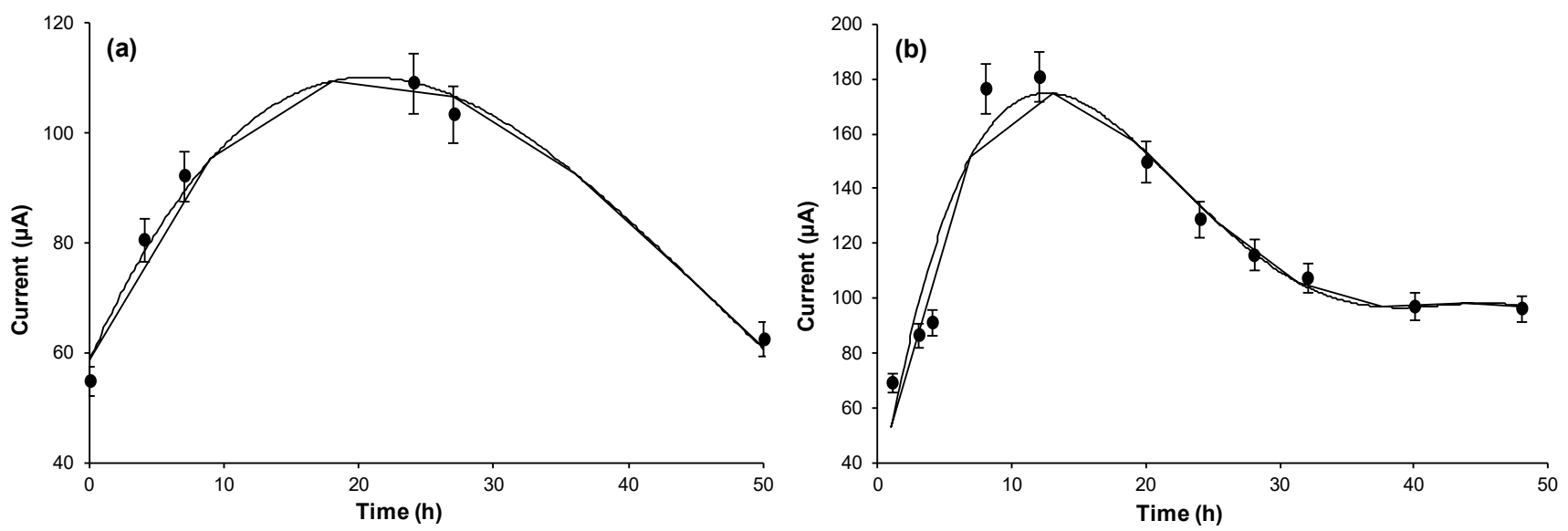

Figure 3. Current intensity recorded as a function of the contact time between yeast cells and glucose (a) operating at $25{ }^{\circ} \mathrm{C}$; (b) operating at $28.5^{\circ} \mathrm{C}$. Yeast concentration: $0.6 \mathrm{~g}$ in $30 \mathrm{~mL}$ of aqueous glycine solution; glucose concentration $0.056 \mathrm{~mol} \mathrm{~L}^{-1}$.
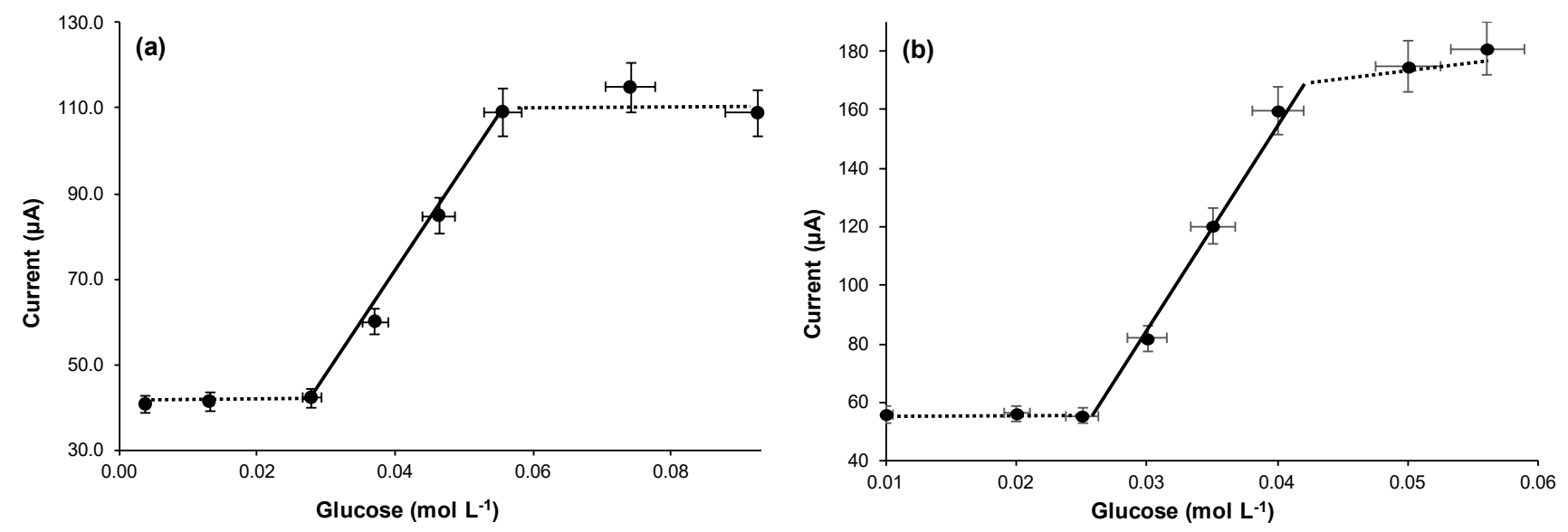

Figure 4. Behavior of current as a function of the increase in glucose concentration (a) operating at $25^{\circ} \mathrm{C}$; (b) operating at $28.5^{\circ} \mathrm{C}$, for a fixed yeast concentration $(0.6 \mathrm{~g}$ in $30 \mathrm{~mL}$ of aqueous glycine solution).

It is not difficult to recognize in the curves of Figures 2-4 the typical trends that correspond to the optimization of an enzymatic process. For example, the trends of the calibration curves in Figure 4 are exactly typical trends of enzyme reaction in a system 
in which the concentration of the enzyme is fixed and maintained constant. In this case the increase in the quantity of substrate causes an increase in the speed of the enzymatic reaction until reaching a current plateau, where the current remains constant. Furthermore, in the case of the other curves (Figures 2 and 3) there is a plateau or bell-like trend, since, as in the case of enzymatic reactions, a limiting factor intervenes; for example, in the case of Figure 2, the limiting factor is the concentration of the substrate (glucose) which therefore remains constant. While similarly, in Figure 3, it is clear that, as the enzymesubstrate contact time increases, the concentration of the ethanol produced increases and consequently also the current produced by the fuel cell. At the end of the curve there is a decrease in the response, since over time some yeast cells tend to deteriorate, so even the functioning of the enzymatic system (which is the yeast's motor) tends to slow down, decreasing the ethanol produced and therefore the current signal of the fuel cell.

Table 1 lists the linearity range and all the main analytical data of calibration curve.

Table 1. Main analytical data using Direct Catalytic Fuel Cell (DCFC) as glucose sensor. Equation of calibration curves as current vs. glucose concentration.

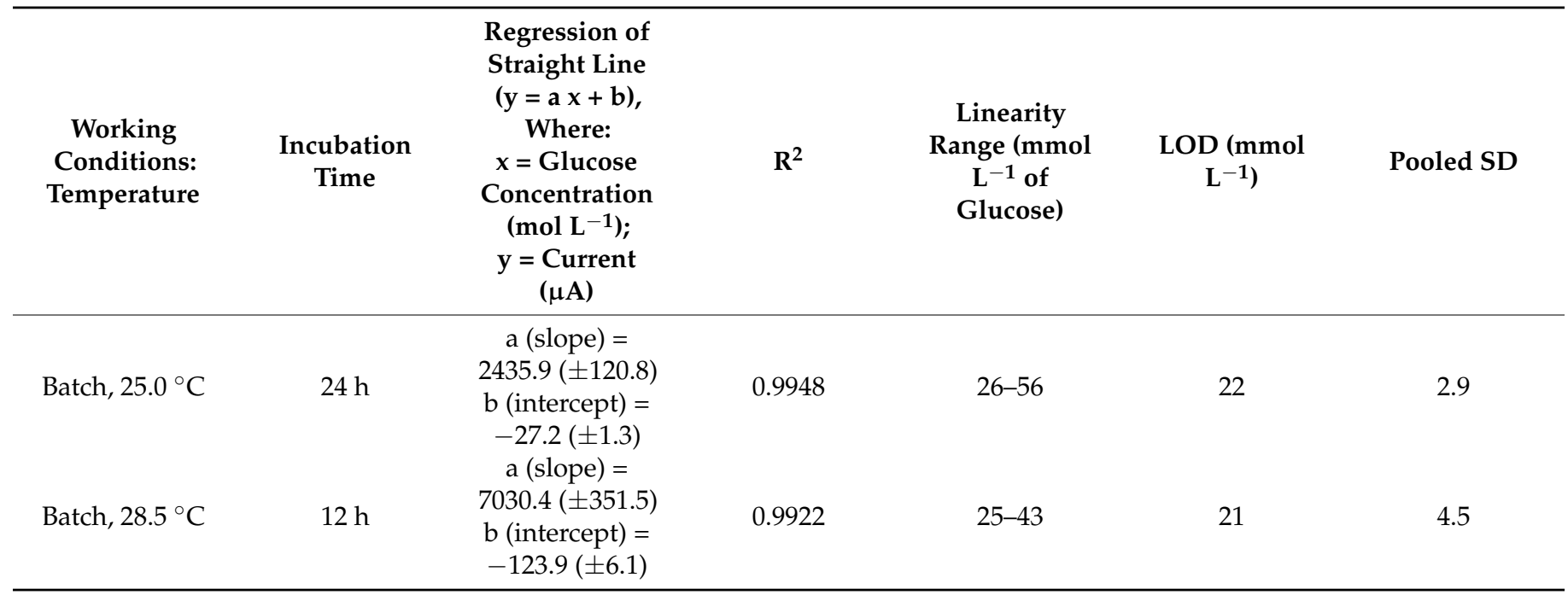

Most features of the fuel cell as glucose sensors can be summarized as follows: the width of the linearity range is slightly less than $1 / 2$ decade (between about 26 and $56 \mathrm{mmol} \mathrm{L}^{-1}$ of glucose) and the low detection limit is approximately $22 \mathrm{mmol} \mathrm{L}^{-1}$ of glucose.

It can be seen as the output current, with a glucose concentration of about $0.056 \mathrm{~mol} \mathrm{~L}^{-1}$, is of the order of $110 \mu \mathrm{A}$. This glucose concentration corresponds to the saturation of the response curve (see Figure 4a). The output current was compared with that obtained using standard ethanol concentration (see Figure $4 \mathrm{~b}$ of work in Ref. [4] of present paper). From this value it was estimated that from a glucose solution of $0.056 \mathrm{~mol} \mathrm{~L}^{-1}$ about $0.004 \mathrm{~mol} \mathrm{~L}^{-1}$ of ethanol was produced. At this glucose concentration the generated current was about $110 \mu \mathrm{A}$ corresponding to approximately $200 \mu \mathrm{W}$ of electrical power.

To this point we considered some literature results, which suggested that the rate of the described reaction-catalyzed by yeast-improves, increasing the temperature [19].

Figure 5 shows the current, at constant glucose concentration (about $56 \mathrm{mmol} \mathrm{L}^{-1}$ ), vs. temperature. It shows that from $25^{\circ} \mathrm{C}$ to $30^{\circ} \mathrm{C}$, the current value was about duplicate, remaining almost stable above $28.5^{\circ} \mathrm{C}$. But more interestingly, the incubation time, which needed to reach the maximum current, decreased noticeably if the incubation temperature increased from $25^{\circ} \mathrm{C}$ to $28.5^{\circ} \mathrm{C}$, as can be observed in Figure $3 \mathrm{~b}$, which shows the current output as a function of the incubation time, recorded while keeping the cell at $28.5^{\circ} \mathrm{C}$. In fact, compared to the curve in Figure $3 a$, measured at $25^{\circ} \mathrm{C}$, with the curve in Figure $3 b$, we can see that the peak at $28^{\circ} \mathrm{C}$ is reached after only $12 \mathrm{~h}$ of incubation time, i.e., in half time respect to the one necessary at $25^{\circ} \mathrm{C}$. While, in practice, the analytical properties of 
the cell did not change noticeably (see the comparison in Table 1) with the small increase of temperature $\left(+3.5^{\circ} \mathrm{C}\right)$, but the incubation time, to reach the maximum of the output current, was definitely shorter.

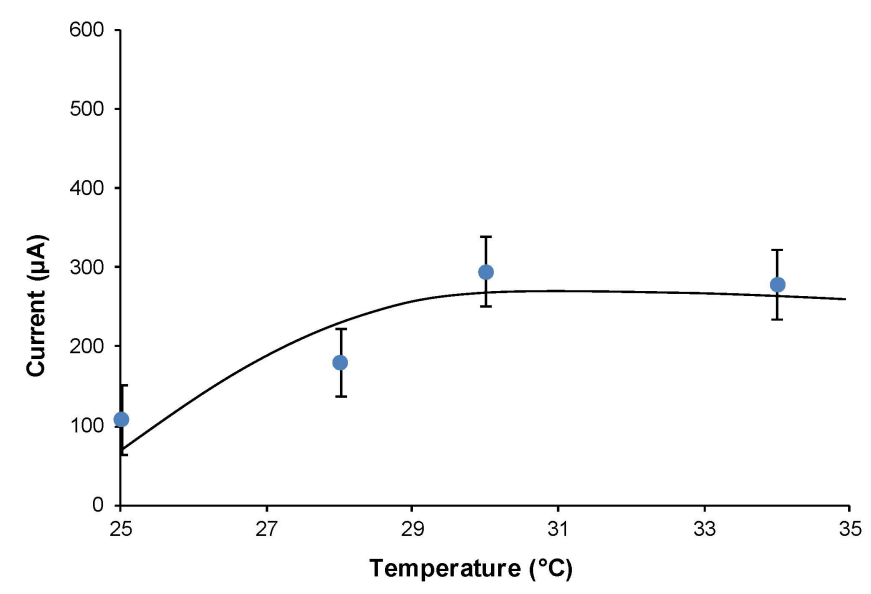

Figure 5. Current intensity recorded as the incubation temperature increases, obtained using $56 \mathrm{mmol} \mathrm{L}^{-1}$ of glucose concentration and $0.6 \mathrm{~g}$ in $30 \mathrm{~mL}$ of yeast.

In this case too, is easy to believe that the enzymatic activity, present in the yeast, tends to increase with temperature, but then (around $28-30{ }^{\circ} \mathrm{C}$ ) the activity tends to stabilize and, if we go over this temperature, the curve could go down, as the yeast would start to deteriorate.

The response of the glucose-fed cell was compared (using the optimized experimental condition) to those obtained using four different carbohydrates: xylose, fructose, galactose, and sucrose. The output current using $0.03 \mathrm{~mol} \mathrm{~L}^{-1}$ of each carbohydrate shows that the largest current value is obtained from sucrose disaccharide $(195.69 \pm 0.03 \mu \mathrm{A})$. While two of three other considered monosaccharides gave currents from $77 \pm 0.03$, to $82 \pm 0.03 \mu \mathrm{A}$, except the case of fructose which produced about $119.06 \pm 0.0 \mu \mathrm{A}$.

Finally, the fuel cell was used as a sensor to estimate the pool of total carbohydrates (expressed as glucose concentration) in three commercial soft drinks, tested as such, after dissolving $0.34 \mathrm{~g}$ of glycine in $30 \mathrm{~mL}$ of each beverage sample, adding $0.6 \mathrm{~g}$ of yeast, then incubating at $28.5^{\circ} \mathrm{C}$ for $12 \mathrm{~h}$, lastly recording the output current from fuel cell $(\mu \mathrm{A})$ after $60 \mathrm{~min}$ from the injection of the beverage in the cell. The achieved analytical results are listed in Table 2, where the fuel cell estimates are compared with those obtained from standard solutions of glucose and ethanol respectively.

Although Table 2 does not contain the traditional results of a proper analysis, since the nominal values of carbohydrates, contained in soft beverages, were not provided by producer firms, however, it can be concluded that, our device is able to estimate carbohydrate concentration in real soft drinks, or at least to provide an estimate of the "pool" of carbohydrates present, expressing the found "pool" concentration, as $\mathrm{mol} \mathrm{L}^{-1}$ glucose. 
Table 2. Analytical results of three analyzed drinks containing carbohydrates compared to standard solutions of glucose and ethanol.

\begin{tabular}{|c|c|c|c|}
\hline Sample & $\begin{array}{l}\text { Recorded Current }(\mu \mathrm{A}) \\
\quad(\mathrm{RSD} \% \leq 4)\end{array}$ & $\begin{array}{l}\text { Found Concentration of } \\
\text { Ethanol }\left(\mathrm{mol} \mathrm{L}^{-1}\right) \\
\left(\mathrm{RSD}^{\mathrm{a}} \leq 5\right)\end{array}$ & $\begin{array}{l}\text { Found Concentration of } \\
\text { "pool" Carbohydrates } \\
\text { (Expressed as mol } \mathrm{L}^{-1} \text { of } \\
\text { Glucose) }(\mathrm{RDS} \% \leq 5)\end{array}$ \\
\hline $\begin{array}{c}\text { Drink } 1 \text { (containing carbohydrates } \\
\text { as sucrose and glucose). } \\
\text { Incubation time } 12 \mathrm{~h}\end{array}$ & 475.98 & 0.020 & 0.286 \\
\hline $\begin{array}{c}\text { Drink } 2 \text { (containing carbohydrates } \\
\text { as sucrose and glucose). } \\
\text { Incubation time } 12 \mathrm{~h}\end{array}$ & 323.18 & 0.014 & 0.194 \\
\hline $\begin{array}{c}\text { Drink } 3 \text { (containing carbohydrates } \\
\text { as sucrose and glucose). } \\
\text { Incubation time } 12 \mathrm{~h}\end{array}$ & 456.57 & 0.019 & 0.274 \\
\hline $\begin{array}{l}\text { Pure Glucose solution (nominal } \\
\text { value of glucose as mol } \mathrm{L}^{-1} \text { ). } \\
\text { Incubation time } 12 \mathrm{~h}\end{array}$ & 169.95 & - & 0.056 \\
\hline $\begin{array}{l}\text { Ethanol solution (concentration as } \\
\left.\qquad \mathrm{mol} \mathrm{L}^{-1}\right)\end{array}$ & 93.24 & 0.004 & - \\
\hline
\end{tabular}

\section{Discussion}

The main results obtained can be listed as follows:

(a) From an analytical point of view, the width of the linearity range of the method to check glucose, was slightly less than $1 / 2$ decade. The minimum detection limit was about $21 \mathrm{mmol} \mathrm{L}-1$ of glucose, by operating at $28.5^{\circ} \mathrm{C}$.

(b) The present research was carried out at $25^{\circ} \mathrm{C}$, (i.e., at room temperature using a thermostat), in order to verify if the system can operate at this temperature (also without thermostat control) in a closed environment, where the change of temperature can be at most about $1^{\circ} \mathrm{C}$ ). In fact, as already observed in previous research $[4,5]$, where the fuel used was only ethanol, even in the present research, where we used glucose as fuel, it was possible to perform measures at room temperature (but in a closed environment [4]) without thermostating. In these operating conditions the reproducibility did not deteriorate more than 1.5 times, compared to when the measurement was carried out in well thermostated mode.

(c) As expected, by carefully increasing the thermostating temperature of the measurement, it could be possible to shorten the measurement time, however investigation carried out in present research, which varied operating temperature conditions, has shown that, by thermostating the system at $28.5^{\circ} \mathrm{C}$ (instead $25^{\circ} \mathrm{C}$ ), the incubation time is reduced from 24 to about $12 \mathrm{~h}$, with the important benefit of shortening the measurement time.

(d) In addition, it has been experimentally verified that the system we proposed is also able to respond to several carbohydrates other than glucose. Lastly it was found suitable to estimate the carbohydrates "pool" of real samples (soft drinks) containing, in addition to glucose, also other types of carbohydrates, such as sucrose, fructose and so on.

(e) The conversion of chemical energy into electrical energy was shortly studied by comparing the current value $(\mu \mathrm{A})$ obtained from a glucose solution at a concentration of $0.056 \mathrm{~mol} \mathrm{~L}^{-1}$, with the same obtained from a standard concentration of EtOH solution. It can be concluded that, from a glucose solution equal to about $0.056 \mathrm{~mol}$ $\mathrm{L}^{-1}$ and after $12 \mathrm{~h}$ of incubation time, about $0.004 \mathrm{mmol} \mathrm{L}^{-1}$ of EtOH can be obtained. Thus, $0.056 \mathrm{~mol} \mathrm{~L}^{-1}$ glucose concentration generates approximately $110 \mu \mathrm{A}$, i.e., it supplies a power of about $200 \mu \mathrm{W}$. 


\section{Conclusions}

It has been experimentally shown that a yeast fuel cell is suitable for both analytical purposes (glucose determination) and energy production using glucose as fuel. It was also demonstrated that the system responds not only to glucose, but also to several other carbohydrates, such as sucrose, fructose, galactose, and xylose. These results, from an analytical point of view, encourage us to move forward in this research, by applying the method to other real samples containing glucose, or other carbohydrates, using the optimized conditions. It is also clear that this result implies that our fuel cell-yeast system can be extended to other types of substrates containing different carbohydrates. Of course, this last circumstance could also be very useful in the energy conversion field, to produce electricity by converting the chemical energy of rather cheap carbohydrates such as sucrose. The next development of the present research will concern the possibility of carrying out measurements in flow conditions rather than in batch. Some experiments in this sense have already been carried out by us and have shown that, by working under flow conditions, it certainly does not improve analytical performance, however this operating mode is very important from an energy production point of view.

Author Contributions: Conceptualization, M.T. and L.C.; methodology, M.T. and E.D.; writing original paper M.T. draft preparation E.D. and M.C.; writing-review and editing, C.D.N., M.P.S. and, M.T.; supervision, C.D.N.; All authors have read and agreed to the published version of the manuscript.

Funding: This research received no external funding.

Institutional Review Board Statement: Not applicable.

Informed Consent Statement: Not applicable.

Data Availability Statement: Data is contained within the article.

Conflicts of Interest: The authors declare no conflict of interest.

\section{References}

1. Parsons, E.G.S. Fuel Cell Handbook, 5th ed.; U.S. Department of Energy: Morgantown, WV, USA, 2000.

2. Metha, V.; Cooper, J.S. Review and analysis of PEM fuel cell design and manufacturing. J. Power Sources 2003, $114,32-53$.

3. Liang, Z.-X.; Zhao, T.S. Catalysts for Alcohol-Fuelled Direct Oxidation Fuel Cells; RSC Energy and Environment Series No. 6; The Royal Society of Chemistry: Cambridge, UK, 2012.

4. Tomassetti, M.; Angeloni, R.; Merola, G.; Castrucci, M.; Campanella, L. Catalytic fuel cell used as an analytical tool for methanol and ethanol determination. Application to ethanol determination in alcoholic beverages. Electrochim. Acta 2016, 191, 1001-1009. [CrossRef]

5. Tomassetti, M.; Merola, G.; Angeloni, R.; Marchiandi, S.; Campanella, L. Further development on DMFC device used for analytical purpose: Real applications in the pharmaceutical field and possible in biological fluids. Anal. Bioanal. Chem. 2016, 408, 7311-7319. [CrossRef] [PubMed]

6. Tomassetti, M.; Pellegrini, S.; Angeloni, R.; Merola, G.; Campanella, L. Checking Ethanol in Several Pharmaceutical Formulations Using Two Different Enzyme Sensor Methods Working by Different Formats. Curr. Pharm. Anal. 2017, 13, 543-551. [CrossRef]

7. Torigoe, K.; Takahashi, M.; Tsuchiya, K.; Iwabata, K.; Ichihashi, T.; Sakaguchi, K.; Sugawara, F.; Abe, M. High-Power Abiotic Direct Glucose Fuel Cell Using a Gold-Platinum Bimetallic Anode Catalyst. ACS Omega 2018, 3, 18323-18333. [CrossRef] [PubMed]

8. Brouzgou, A.; Tsiakaras, P. Electrocatalysts for Glucose Electrooxidation Reaction: A Review. Rev. Top Catal. 2015, 58, 1311-1327. [CrossRef]

9. Oncescu, V.; EricksonHigh, D. High volumetric power density, non-enzymatic, glucose fuel cells. Sci. Rep. 2013, 3, 1226. [CrossRef] [PubMed]

10. Kloke, A.; Biller, B.; Kräling, U.; Kerzenmacher, S.; Zengerle, R.; Von Stetten, F. A Single Layer Glucose Fuel Cell Intended as Power Supplying Coating for Medical Implants. Fuel Cells 2011, 11, 316-326. [CrossRef]

11. Aghahosseini, H.; Ramazani, A.; Asiabi, P.A.; Gouranlou, F.; Hosseini, F.; Rezaei, A.; Min, B.-K.; Joo, S.W. Glucose-based Biofuel Cells: Nanotechnology as a Vital Science in Biofuel Cells Performance. Nanochem. Res. 2016, 1, 183-204.

12. Barelli, L.; Bidini, G.; Calzoni, E.; Cesaretti, A.; Di Michele, A.; Emiliani, C.; Gammaitoni, L.; Sisani, E. Enzymatic fuel cell technology for energy production from bio-sources. In Proceedings of the 74th ATI National Congress, AIP Conference Proceedings, Modena, Italy, 11-13 September 2019; AIP Publishing LLC: 1305 Walt Whitman Road, Melville, NY, USA, 2019. 
13. Kizling, M.; Dzwonek, M.; Nowak, A.; Tymecki, L.; Stolarczyk, K.; Wieckowska, A.; Bilewicz, R. Multi-Substrate Biofuel Cell Utilizing Glucose, Fructose and Sucrose as the Anode Fuels. Nanomaterials 2020, 10, 1534. [CrossRef] [PubMed]

14. Cosnier, S.; Le Goff, A.; Holzinger, M. Towards Glucose Biofuel Cells Implanted in Human Body for Powering Artificial Organs: Review. Electrochem. Commun. 2014, 38, 19-23. [CrossRef]

15. Capodaglio, A.G.; Molognoni, D.; Dallago, E.; Liberale, A.; Cella, R.; Longoni, P.; Pantaleoni, L. Microbial Fuel Cells for Direct Electrical Energy Recovery from Urban Wastewaters. Sci. World J. 2013, 2013, 634738. [CrossRef]

16. Slate, A.J.; Whitehead, K.A.; Brownson, D.A.C.; Banks, C.E. Microbial Fuel Cells: An Overview of Current Technology. Renew. Sust. Energy Rev. 2019, 101, 60-81. [CrossRef]

17. Sayed, E.T.; Abdelkareem, M.A. Yeast as a Biocatalyst in Microbial Fuel Cell. In Old Yeasts—New Questions; Lucas, C., Pais, C., Eds.; Headquarters IntechOpen Limited: London, UK, 2017; ISBN 978-953-51-3678-1.

18. Liu, H.; Song, C.; Zhang, L.; Zhang, J.; Wang, H.; Wilkinson, D.P. A Review of Anode Catalysis in the Direct Methanol Fuel Cell. J. Power Sources 2006, 155, 95-110. [CrossRef]

19. Dragone, R.; Frazzoli, C.; Grasso, G.; Rossi, G. Sensor with Intact or Modified Yeast Cells as Rapid Device for Toxicological Test of Chemicals. J. Agric. Chem. Environ. 2014, 3, 35-40. [CrossRef] 